\title{
Pengaruh Psikokuratif terhadap Kadar VEGF-c, Kortisol dan Skor HADS Pasien Kanker Serviks Stadium Lanjut
}

\author{
Soetrisno ${ }^{1}$, Sri Sulistyowati ${ }^{2}$, Rubin Enhui Tjiang ${ }^{3}$, Hari Wujoso ${ }^{4}$, Hafi Nurinasari ${ }^{5}$, Erindra Budi ${ }^{6}$ \\ ${ }_{1,2,3,5}$ Bagian Obstetri dan Ginekologi Fakultas Kedokteran Universitas Sebelas Maret/ \\ RSUD Dr. Moewardi Surakarta/ (0271) 665145 \\ ${ }^{4}$ Bagian Forensik dan Medikolegal RSUD Dr. Moewardi Surakarta \\ ${ }^{6}$ Diploma Kebidanan Fakultas Kedokteran Universitas Sebelas Maret Surakarta \\ email : soetrisno spogk@yahoo.com, bean83co@yahoo.com, elis spog@yahoo.co.id
}

\begin{abstract}
Background: Cancer diagnosis and therapy that causes chronic stress, its progression to depression increase cortisol and VEGF-c levels in advanced cervical cancer patients

Objective: To know the VEGF-c, cortisol and HADS level in advanced stage cervical cancer patients who get Psychocurative intervention

Method : An experimental study of pretest - posttest controle group design in outpatient oncology clinic and ward of Doctor Moewardi General Hospital. Thirty subjects with advanced cervical cancer were randomly divided into 15 patients in the intervention group, and 15 in control. Psychocurative intervention 4 times a month, 1 time a week, 60 minutes duration. Before and after intervention, each subject of the two groups was examined levels of VEGF-c, cortisol and HADS scores. Data obtained were analyzed by independent t test, Mann Whitney, Pair t and Wilcoxon with the 19th version of SPSS for Windows.

Result and Discussion: Average VEGF-c levels before intervention $9006.53 \pm 2181.49$, after intervention $5631.20 \pm 2071.55, p<0.001$. The mean cortisol level before intervention was $12.29 \pm 4.36$, after intervention $6.71 \pm 3.88, p<0.001$. The mean HADS Anxiety score before intervention was $14.13 \pm 3.02$, after intervention $8.47 \pm 3.07, \mathrm{p}<0.001$. Mean Depression HADS scores before intervention $13.80 \pm 3.21$, after intervention $7.20 \pm 2.70$, $\mathrm{p}<0.001$.

Conclusion : VEGF-c levels, cortisol, HADS anxiety scores and depression in patients with advanced cervical cancer decline after psychocurative intervention.
\end{abstract}

Keywords : Psychocurative; VEGF-c; Cortisol; HADS; Cervical cancer

\begin{abstract}
ABSTRAK
Latar Belakang: Diagnosis dan terapi kanker menimbulkan stres kronis yang dapat berkembang menjadi depresi sehingga meningkatkan kadar kortisol dan VEGF-c pada pasien kanker serviks stadium lanjut.

Tujuan: Mengetahui pengaruh Psikokuratif terhadap kadar VEGF-c, kortisol dan skor HADS pada pasien kanker serviks stadium lanjut.

Metode: Studi eksperimental pretest - posttest controle group design lakukan di poli dan bangsal onkologi ginekologi RS Dr. Moewardi Surakarta. Sebanyak 30 subyek kanker serviks stadium lanjut, di bagi secara random 15 pasien kelompok perlakuan, dan 15 lainnya kontrol. Perlakuan berupa psikokuratif 4 kali dalam sebulan, 1 kali dalam seminggu, durasi 60 menit. Sebelum dan setelah perlakuan, setiap subyek kedua kelompok diperiksa kadar VEGF-c, kortisol dan skor HADS. Data yang diperoleh di analisa dengan uji independent $t$, Mann Whitney, Pair $t$ dan Wilcoxon dengan SPSS versi ke-19 untuk Windows.

Hasil dan Pembahasan: Rerata kadar VEGF-c sebelum perlakuan $9006.53 \pm 2181.49$, setelah perlakuan $5631.20 \pm 2071.55$, $p<0,001$. Rerata kadar kortisol sebelum perlakuan $12.29 \pm 4.36$, setelah perlakuan $6.71 \pm 3.88, p<0,001$. Rerata skor HADS Anxiety sebelum perlakuan $14.13 \pm 3.02$, setelah perlakuan $8.47 \pm 3.07, p<0,001$. Rerata skor HADS Depresi sebelum perlakuan $13.80 \pm 3.21$, setelah perlakuan $7.20 \pm 2.70, p<0,001$.

Kesimpulan: Kadar VEGF-c, kortisol, skor HADS anxiety dan depresi pasien kanker serviks stadium lanjut menurun setelah intervensi psikokuratif.
\end{abstract}

Kata kunci: Psikokuratif; VEGF-c; kortisol; HADS; Kanker serviks 


\section{PENDAHULUAN}

Kanker serviks dan payudara merupakan penyakit kanker dengan prevalensi tertinggi di Indonesia pada tahun 2013, yaitu kanker serviks sebesar $0,8 \%$ o dan kanker payudara sebesar $0,5 \%{ }^{1}$ Stres emosional merupakan ko-morbid tersering yang menyerang penderita kanker serviks stadium lanjut, lebih dari $10 \%$ nya mengalami depresi. Dalam sebuah studi meta-analisis mengungkapkan bahwa depresi mayor maupun minor meningkatkan angka mortalitas sebesar $39 \%{ }^{2}$ Saat ini penanganan kanker serviks stadium lanjut belum optimal, karena depresi pada pasien pasien tersebut sering tidak terdiagnosis dan tidak mendapat penanganan yang serius, karena adanya anggapan bahwa depresi adalah suatu keadaan yang wajar, yang merupakan suatu reaksi universal terhadap penyakit serius dan sebagian reaksi tersebut timbul dalam bentuk neurovegetatif. ${ }^{3}$ Soetrisno mengatakan bahwa pemberian psikokuratif yang terdiri atas dukungan kognitif, sosial, spiritual, dan fisik pada pasien yang mengalami distres dapat menurunkan intensitasnya. ${ }^{4}$ Interaksi yang kompleks antara sistem endokrin, sistem saraf, dan sistem imun memberikan kesempatan untuk perkembangan terapi yang efektif dan lebih cepat untuk menangani depresi pada pasien kanker stadium lanjut di kemudian hari dengan dampak meningkat kualitas hidupnya (Quality of Life .) $)^{5}$ Pasien dengan kanker serviks dengan ekspresi VEGF-c yang tinggi menunjukkan adanya invasi stroma, metastasis ke pembuluh darah dan kelenjar limfe ${ }^{6}$. Kortisol adalah hormon penolak stresor, tapi apabila di lepaskan terus menerus dapat mengakibatkan penekanan sistem imun. ${ }^{7}$ HADS merupakan metode pengukuran yang sering digunakan untuk mendiagnosis distres fisiologis pada pasien non psikiatrik. ${ }^{8}$

Berdasarkan masalah tersebut di atas, maka diperlukan penelitian mengenai pengaruh psikokuratif terhadap kadar VEGF-c, kortisol dan skor HADS pada pasien kanker serviks stadium lanjut.

\section{METODE}

Penelitian ini merupakan studi eksperimental dengan rancangan penelitian Pretest-Postest Control Group Design pada pasien kanker serviks stadium lanjut. Penelitian dilakukan di poli dan bangsal onkologi ginekologi RS Dr. Moewardi Surakarta pada bulan Februari sampai dengan Maret 2019. Subyek penelitian adalah pasien kanker serviks stadium lanjut (IIB-IV) yang memenuhi kriteria inklusi dan eksklusi yang memeriksakan diri di Poli maupun bangsal Onkologi Ginekologi RSUD Dr.Moewardi Surakarta. Kriteria Inklusi adalah pasien kanker serviks stadium lanjut (IIB atau lebih) yang telah di buktikan dengan hasil patologi anatomi, telah mendapatkan terapi adjuvan radioterapi dan kemoterapi. Kriteria eksklusi adalah adanya gangguan jiwa berat dengan gejala psikotik, pasien yang mengalami gangguan multi organ berat, skor HADS menunjukkan kecemasan atau depresi berat yang membutuhkan pengobatan psikofarmaka dan psikiater dan terdapat riwayat pengobatan depresi. Pemberian pelatihan psikokuratif sesuai dengan pedoman modul yang telah dibuat. Sesi latihan dilakukan sebanyak $4 x$ dalam sebulan, 1 kali dilakukan bersama di RSUD Dr. Moewardi , 3 kali dilakukan sendiri di rumah dengan supervisi dari peneliti, durasi pertemuan 60 menit.

Sebelum dan sesudah intervensi, dilakukan pemeriksaan kadar VEGF-c, kortisol dan skor HADS. Subyek penelitian berjumlah 60 orang penderita kanker serviks stadium lanjut diberi nomor undian secara acak, yang mendapatkan nomor ganjil di kelompokkan ke kelompok intervensi, sedangkan nomor genap dalam kelompok kontrol. Untuk kelompok intervensi diperiksa pada hari yang berbeda dengan kelompok kontrol untuk menjaga validitas.

Pemeriksaan kadar VEGF-c, dan Kortisol dilakukan di Ruang Poli Ginekologi pada pagi hari sesuai ritme irama sirkadian tubuh. Sedangkan skor HADS di isi langsung oleh subyek penelitian pada lembar kuesioner dan diberikan penilaian langsung oleh peneliti.

Kode etik penelitian dijalankan dengan memberikan informed consent, memberikan inisial nama, menjaga kerahasiaan, dan sesuai dengan norma yang berlaku. Kelaikan etika pada penelitian ini sesuai dengan Surat Kelaikan etik yang diterbitkan oleh Rumah Sakit Dr. Moewardi no. 1.147/ IV/ HREC/ 2019. 


\section{HASIL DAN PEMBAHASAN}

Kelompok kontrol dan intervensi masing-masing berjumlah 15 orang. Karakteristik subyek penelitian diketahui bahwa usia pasien pada kelompok intervensi rata-rata 48,80 \pm 7,07 tahun dan usia pasien pada kelompok kontrol rata-rata 47,00 \pm 5,93 tahun. Indeks Massa Tubuh (IMT) pasien pada kelompok intervensi rata-rata $21.40 \pm 1.76$ dan IMT pasien pada kelompok kontrol rata-rata 21,53 \pm 1 ,96. Pekerjaan pasien pada kelompok intervensi sebagian besar ibu rumah tangga (IRT) sebanyak 9 pasien $(60,0 \%)$ dan pekerjaan pasien pada kelompok kontrol sebagian besar juga IRT sebanyak 9 pasien $(60,0 \%)$. Paritas pasien pada kelompok intervensi sebagian besar multipara sebanyak pasien $(53,3 \%)$ dan paritas pasien pada kelompok kontrol sebagian besar multipara dan sekundipara yaitu masing masing sebanyak 6 pasien $(40,0 \%)$. Pendidikan pasien pada kelompok intervensi sebagian besar dengan tingkat dasar sebanyak 8 pasien $(53,3 \%)$ dan pendidikan pasien pada kelompok kontrol sebagian besar tingkat menengah sebanyak 11 pasien $(73,3 \%)$.

Tabel 1 menunjukkan karakteristik pasien berupa usia, IMT, pekerjaan, paritas, dan tingkat pendidikan mendapatkan nilai $(p>0,05)$ yang berarti bahwa tidak menunjukan perbedaan yang signifikan atau homogen antara intervensi dan kontrol.

Tabel 1. Karakteristik Subyek Penelitian

\begin{tabular}{lccc}
\multirow{2}{*}{ Karakteristik } & \multicolumn{2}{c}{ Kelompok } & p \\
\cline { 2 - 3 } Usia & Intervensi & Kontrol & 0,456 \\
IMT & $48,80 \pm 7,07$ & $47,00 \pm 5,93$ & 0,817 \\
Pekerjaan & $21,40 \pm 1,76$ & $21,53 \pm 1,96$ & 1,000 \\
IRT & $9(60,0 \%)$ & $9(60,0 \%)$ & \\
Tani & $6(40,0 \%)$ & $6(40,0 \%)$ & \\
Paritas & & & 0,750 \\
Multi & $8(53,3 \%)$ & $6(40,0 \%)$ & \\
Primi & $2(13,3 \%)$ & $3(20,0 \%)$ & \\
Sekundi & $5(33,3 \%)$ & $6(40,0 \%)$ & \\
Pendidikan & & & 0,136 \\
Dasar & $8(53,3 \%)$ & $4(26,7 \%)$ & \\
Menengah & $7(46,7 \%)$ & $11(73,3 \%)$ & \\
\hline
\end{tabular}

Perbedaan VEGF-c pretest dan posttest antara kelompok intervensi dan kontrol pada pasien kanker serviks stadium lanjut digambarkan pada tabel 2, di mana kadar VEGF-c lebih rendah setelah dilakukan intervensi psikokuratif.

Tabel 2. Perbedaan VEGF-c pretest dan posttest antara kelompok intervensi dan kontrol pada pasien kanker serviks stadium lanjut

\begin{tabular}{|c|c|c|c|c|}
\hline \multirow{2}{*}{ Kelompok } & \multirow{2}{*}{$\mathrm{n}$} & \multicolumn{2}{|c|}{ VEGF-c } & \multirow{2}{*}{$p$-value } \\
\hline & & Pretest & Posttest & \\
\hline Intervensi & 15 & $9006,53 \pm 2181,49$ & $5631,20 \pm 2071,55$ & $<0,001$ \\
\hline Kontrol & 15 & $8673,27 \pm 2465,72$ & $8011,27 \pm 2835,05$ & 0,159 \\
\hline$p$-value & & 0,698 & 0,014 & \\
\hline
\end{tabular}


Berdasarkan Tabel 2 diketahui bahwa pada pasien kanker serviks stadium lanjut kelompok intervensi, kadar VEGF-c pretest rata-rata 9006,53 \pm 2181,49; kemudian posttest rata-rata 5631,20 \pm 2071,55; hasil uji berpasangan mendapatkan nilai $p<0,001(p<0,05)$, yang berarti bahwa terdapat perbedaan yang signifikan kadar VEGF-c pretest dan posttest.

Kadar VEGF-c pasien kanker serviks stadium lanjut kelompok kontrol pretest rata-rata 8673,27 $\pm 2465,72$; kemudian setelah posttest rata-rata $8011,27 \pm 2835,05$; hasil uji pair $t$ mendapatkan nilai $p=0,159(p>0,05)$, yang berarti bahwa tidak terdapat perbedaan yang signifikan kadar VEGF-c pretest dan postest.

VEGF-c pasien kanker serviks stadium lanjut kelompok intervensi sebelum intervensi (pretest) rata-rata 9006,53 $\pm 2181,49$; kemudian kelompok kontrol sebelum intervensi (pretest) dengan VEGF-c rata-rata $8673,27 \pm 2465,72$; hasil uji independent $t$ mendapatkan nilai $p=0,698(p<0,05)$, yang berarti bahwa tidak terdapat perbedaan yang signifikan.

VEGF-c pasien kanker serviks stadium lanjut kelompok intervensi sesudah intervensi (posttest) rata-rata 5631,20 \pm 2071,55; kemudian kelompok kontrol sesudah intervensi (posttest) ratarata $8011,27 \pm 2835,05$; hasil uji independent $t$ mendapatkan nilai $p=0,014(p>0,05)$, yang berarti bahwa terdapat perbedaan yang signifikan

Perbedaan kortisol pretest dan posttest antara kelompok intervensi dan kontrol pada pasien kanker serviks stadium lanjut digambarkan pada tabel 3, di mana di mana kadar kortisol lebih rendah setelah dilakukan intervensi psikokuratif.

Tabel 3. Perbedaan VEGF-c pretest dan posttest antara kelompok intervensi dan kontrol pada pasien kanker serviks stadium lanjut

\begin{tabular}{|c|c|c|c|c|}
\hline \multirow{2}{*}{ Kelompok } & \multirow{2}{*}{$\mathrm{n}$} & \multicolumn{2}{|c|}{ Kortisol } & \multirow[t]{2}{*}{$p$-value } \\
\hline & & Pretest & Posttest & \\
\hline Intervensi & 15 & $12,29 \pm 4,36$ & $6,71 \pm 3,88$ & $<0,001$ \\
\hline Kontrol & 15 & $12,07 \pm 3,87$ & $11,60 \pm 3,85$ & 0,083 \\
\hline$p$-value & & 0,901 & 0,002 & \\
\hline
\end{tabular}

Berdasarkan Tabel 3 diketahui bahwa pada pasien kanker serviks stadium lanjut kelompok intervensi pretest kadar kortisol rata-rata 12,29 \pm 4,36; kemudian posttest rata-rata $6,71 \pm 3,88$; hasil uji berpasangan mendapatkan nilai $p<0,001$ $(p<0,05)$, yang berarti bahwa terdapat perbedaan yang signifikan kortisol antara pretest dan posttest pada kelompok intervensi.

Kadar kortisol pasien kanker serviks stadium lanjut kelompok kontrol pretest rata-rata 12,07 \pm 3,87; kemudian posttest rata-rata 11,60 $\pm 3,85$; hasil uji Wilcoxon mendapatkan nilai $p=0,083(p>0,05)$, yang berarti bahwa tidak terdapat perbedaan yang signifikan kortisol antara pretest dan postest pada kelompok kontrol.

Kadar kortisol pasien kanker serviks stadium lanjut kelompok intervensi sebelum intervensi (pretest) rata-rata $12,29 \pm 4,36$; kemudian kelompok kontrol sebelum intervensi (pretest) dengan kortisol rata-rata $12,07 \pm 3,87$; hasil uji Mann Whitney mendapatkan nilai $p<0,901(p<0,05)$, yang berarti bahwa tidak terdapat perbedaan yang signifikan

Kadar kortisol pasien kanker serviks stadium lanjut kelompok intervensi sesudah intervensi (posttest) rata-rata $6.71 \pm 3.88$, kemudian kelompok kontrol sesudah intervensi (posttest) rata-rata 11.60 \pm 3.85 , hasil uji independent $t$ mendapatkan nilai $p=0,002(p>0,05)$, yang berarti bahwa terdapat perbedaan yang signifikan

Perbedaan Skor HADS Anxiety pretest dan posttest antara kelompok intervensi dan kontrol pada pasien kanker serviks stadium lanjut digambarkan pada tabel 4, di mana Skor HADS Anxiety lebih rendah setelah dilakukan intervensi psikokuratif. 
Tabel 4. Perbedaan Skor HADS Anxiety pretest dan posttest antara kelompok intervensi dan kontrol pada pasien kanker serviks stadium lanjut

\begin{tabular}{|c|c|c|c|c|}
\hline \multirow{2}{*}{ Kelompok } & \multirow{2}{*}{$\mathrm{n}$} & \multicolumn{2}{|c|}{ HADS Anxiety } & \multirow[t]{2}{*}{$p$-value } \\
\hline & & Pretest & Posttest & \\
\hline Intervensi & 15 & $14.13 \pm 3.02$ & $8.47 \pm 3.07$ & 0,001 \\
\hline Kontrol & 15 & $12.87 \pm 2.47$ & $12.27 \pm 2.52$ & 0,082 \\
\hline$p$-value & & 0,174 & 0,001 & \\
\hline
\end{tabular}

Berdasarkan Tabel 4 diketahui bahwa pada pasien kanker serviks stadium lanjut kelompok intervensi, HADS Anxiety pretest rata-rata 14.13 \pm 3.02 , kemudian setelah posttest rata -rata $8.47 \pm$ 3.07, hasil uji Wilcoxon mendapatkan nilai $p<0,001$ $(p<0,05)$, yang berarti bahwa terdapat perbedaan yang signifikan HADS Anxiety antara pretest dan posttest pada kelompok intervensi.

HADS Anxiety pasien kanker serviks stadium lanjut kelompok kontrol pretest rata-rata $12.87 \pm$ 2.47, kemudian setelah intervensi (posttest) ratarata $12.27 \pm 2.52$, hasil uji pair $t$ mendapatkan nilai $p=0,082(p>0,05)$, yang berarti bahwa tidak terdapat perbedaan yang signifikan HADS Anxiety antara pretest dan posttest pada kelompok kontrol.

HADS (Anxiety) pasien kanker serviks stadium lanjut kelompok intervensi sebelum intervensi (pretest) rata-rata $14.13 \pm 3.02$, kemudian kelompok kontrol (pretest) rata-rata $12.87 \pm 2.47$, hasil uji Mann Whitney mendapatkan nilai $p=0,174$ ( $p>0,05)$, yang berarti bahwa tidak terdapat per-bedaan yang signifikan antara kelompok intervensi dengan kontrol.

HADS (Anxiety) pasien kanker serviks stadium lanjut kelompok intervensi sesudah intervensi (posttest) rata-rata $8.47 \pm 3.07$, kemudian kelompok kontrol sesudah intervensi (posttest) rata-rata 12.27 \pm 2.52 hasil uji independent $t$ mendapatkan nilai $p<0,001(p>0,05)$, yang berarti bahwa terdapat perbedaan yang signifikan

Perbedaan Skor HADS Depresi pretest dan posttest antara kelompok intervensi dan kontrol pada pasien kanker serviks stadium lanjut digambarkan pada tabel 5, di mana Skor HADS Depresi lebih rendah setelah dilakukan intervensi psikokuratif.

Tabel 5. Perbedaan Skor HADS Depresi pretest dan posttest antara kelompok intervensi dan kontrol pada pasien kanker serviks stadium lanjut

\begin{tabular}{lcccc}
\multirow{2}{*}{ Kelompok } & $\mathrm{n}$ & \multicolumn{2}{c}{ HADS Depresi } & p-value \\
\cline { 3 - 4 } & & Pretest & Posttest & \\
Intervensi & 15 & $13,80 \pm 3.21$ & $7,20 \pm 2,70$ & 0,001 \\
Kontrol & 15 & $12,67 \pm 2.44$ & $12,13 \pm 1,85$ & 0,135 \\
p-value & & 0,286 & $<0,001$ & \\
\hline
\end{tabular}

Berdasarkan Tabel 5 diketahui bahwa pada pasien kanker serviks stadium lanjut kelompok intervensi, HADS Depresi pretest rata-rata 13,80 $\pm 3,21$; kemudian setelah posttest rata-rata 7,20 $\pm 2,70$; hasil uji Wilcoxon mendapatkan nilai $p<0,001$ $(p<0,05)$, yang berarti bahwa terdapat perbedaan yang signifikan HADS Depresi antara pretest dan posttest pada kelompok intervensi.
HADS Depresi pasien kanker serviks kelompok kontrol pretest rata-rata $12,67 \pm 2,44$; kemudian setelah posttest rata-rata $12,13 \pm 1,85$; hasil uji berpasangan mendapatkan nilai $p=0,135$ ( $p>0,05)$, yang berarti bahwa tidak terdapat perbedaan yang signifikan HADS Depresi pretest dan posttest pada kelompok kontrol. 
HADS (Depresi) pasien kanker serviks kelompok intervensi sebelum intervensi (pretest) rata-rata $13,80 \pm 3,21$; kelompok kontrol sebelum intervensi (pretest) rata-rata $12,67 \pm 2,44$; hasil uji Independent $t$ mendapatkan nilai $p=0,286(p>0,05)$, yang berarti bahwa tidak terdapat perbedaan yang signifikan.

HADS (Depresi) pasien kanker serviks kelompok intervensi sesudah intervensi (posttest) rata-rata $7,20 \pm 2,70$; kemudian kelompok kontrol sesudah intervensi (posttest) rata-rata $12,13 \pm 1,85$ hasil uji Mann Whitney mendapatkan nilai $p<0,001$ $(p>0,05)$, yang berarti bahwa terdapat perbedaan yang signifikan

Kelompok yang diberikan terapi tambahan psikokuratif mengalami penurunan kortisol lebih banyak dibandingkan kelompok kontrol pada pasien kanker serviks stadium lanjut. Demikian juga pada kelompok intervensi yang mendapat psikokuratif mengalami penurunan skor VEGF-c lebih banyak dibandingkan kelompok kontrol pada pasien kanker serviks stadium lanjut. Tambahan pemberian psikokuratif mampu menurunkan skor HADS Anxiety dan Depresi lebih banyak dibandingkan dengan kelompok kontrol pada pasien kanker serviks stadium lanjut.

Psikokuratif adalah intervensi psikologis yang diciptakan dengan tujuan meyakinkan bahwa seseorang memiliki kesempatan yang lebih baik untuk menyesuaikan diri pada kondisi dan situasi kejiwaan mereka sehingga dapat mengubah komponen pengetahuan terdahulu dan mendapatkan pemahaman baru untuk mengubah perilaku menjadi lebih baik. Intervensi di maksud adalah upaya pengobatan yang diciptakan dengan tujuan menyakinkan bahwa seseorang memiliki kesempatan yang lebih baik untuk menyesuaikan diri pada kondisi dan situasi kejiwaan mereka dan membangun hubungan harmonis dan intregral untuk meningkatkan stabilitas psikologis dan kemampuan hidup. Psikokuratif terdiri atas dukungan kognitif, spiritual, sosial dan fisik yang bisa merubah kondisi distress menjadi eustress. ${ }^{4}$

Pasien kanker sering mengalami masalah psikologis berhubungan dengan diagnosis, modalitas terapi dan stadium penyakitnya. ${ }^{9}$ Stres merupakan respon biologis individu terhadap stressor, yang dapat di ukur secara objektif dan cepat. $^{5}$ Penelitian menunjukkan bahwa pasien kanker sering merasa frustrasi dan putus asa. ${ }^{10}$ Ketika seseorang di diagnosis menderita kanker, maka seketika itu juga terjadi perubahan yang drastis pada hidupnya, berupa peningkatan stres emosional sampai depresi. ${ }^{11}$ Penanganan kanker sering tidak optimal karena depresi di anggap wajar terjadi pada penderita kanker. ${ }^{3}$ Survival rate sebesar $61,9 \%$ pada pasien kanker serviks stadium lanjut yang telah mendapatkan terapi definitif. ${ }^{12}$

Belum banyak yang diketahui tentang mekanisme dan proses biobehavioral yang mempengaruhi pertumbuhan dan progresivitas dari kanker. ${ }^{13}$ Mekanisme angiogenesis pada jaringan di perantarai oleh VEGF dan konsentrasi oksigen merupakan mekanisme krusial angiogenesis yang di induksi oleh sel tumor. ${ }^{14}$ Peran VEGF sebagai tumor marker yang digunakan untuk prediksi metastasis kelenjar getah bening serta prediksi respon terapi telah di teliti pada berbagai keganasan, di antaranya karsinoma kolorektal, karsinoma hepatoseluler, endometrium dan ovarium. ${ }^{15}$ Cheng et al, menyimpulkan dalam penelitiannya, bahwa serum VEGF merupakan petanda tumor yang potensial, dengan relevansi yang bagus untuk menentukan asal dari massa di adneksa. ${ }^{16}$ Pasien dengan kanker serviks dengan ekspresi VEGF-c yang tinggi menunjukkan adanya invasi stroma, metastasis ke ruang kelenjar limfe pembuluh darah, dan kelenjar limfe. ${ }^{6}$

Aksis HPA adalah sebuah pola perjalanan sinyal di mana stresor yang terdeteksi oleh hipotalamus, akan melepaskan $\mathrm{CRH}$ (Corticotropin releasing hormone), yang akan di deteksi oleh kelenjar pituitari, lalu kelenjar pituitari akan mensekresikan hormon lain yaitu ACTH (Adrenocorticotropic releasing hormone) yang akan masuk ke dalam peredaran darah, dan akhirnya di deteksi oleh kelenjar adrenal. Bagian luar kelenjar adrenal, yaitu korteks adrenal akan melepaskan glukokortikoid, termasuk kortisol sebagai bagian terakhir dari siklus. ${ }^{19}$ Dalam hal menciptakan keseimbangan hormonal dalam darah, kortisol yang telah dilepaskan akan di deteksi oleh hipotalamus, kemudian terjadi mekanisme umpan balik negatif yaitu dengan mengurangi pelepasan $\mathrm{CRH}$ oleh hipotalamus. ${ }^{20}$ Hormon glukokortikoid yang dilepaskan pada proses inilah yang disebut sebagai "penolak/ resist" untuk melawan stresor. 
Tetapi apabila fase penolakan (resistance phase) tidak mampu menstabilkan tubuh pada posisi semula, maka tubuh akan masuk ke dalam fase kelelahan (exhasution phase), dengan karakteristik stres kronis, di mana pelepasan kortisol berlangsung terus menerus untuk melawan stressor, efek jangka panjang yang merugikan adalah peningkatan tekanan darah, gula darah tinggi, dan penekanan sistem imun. ${ }^{7}$ Stres kronis umumnya terkait dengan depresi, anorexia, gangguan obsesif-kompulsif, dan obesitas sentral. ${ }^{21}$

Penurunan kortisol akan berakibat menurunnya mediator stres (norepinefrin, epinefrin, dan isoproterenol) sehingga sekresi VEGF-c pada kanker serviks stadium lanjut menurun. ${ }^{22}$ Penurunan VEGF-c akan mengurangi terjadinya proliferasi dan metastase sel tumor sehingga tumor mengalami regresi dengan dampak penurunan stress emosional, tidak terjadi distress tetapi eustress (stress fisiologis) dan kualitas hidup meningkat. ${ }^{13}$

HADS merupakan metode pengukuran yang sering digunakan untuk mendiagnosis distres fisiologis pada pasien non psikiatrik. ${ }^{8}$ Beberapa studi menyebutkan bahwa komponen internal HADS memiliki hasil yang memuaskan dan konsistensi dalam mengukur kecemasan dan depresi pada populasi umum termasuk pasien kanker. ${ }^{17}$ Instrumen HADS terjemahan versi Bahasa Indonesia menunjukkan reliabilitas yang baik dengan interrater agreement menunjukkan kesepakatan yang baik, sehingga HADS ini dapat digunakan sebagai instrumen pemeriksaan yang reliabel atau dapat dipercaya. ${ }^{18}$ HADS di rekomendasikan untuk mengukur perubahan kecemasan dan depresi setelah dilakukan intervens. ${ }^{23}$

\section{KESIMPULAN DAN SARAN}

Berdasarkan penelitian ini, dapat di simpulkan bahwa pemberian psikokuratif berpengaruh terhadap penurunkan kadar VEGF-c, kortisol dan skor HADS pasien kanker serviks stadium lanjut.

\section{DAFTAR PUSTAKA}

1. Kemenkes RI. Situasi Penyakit Kanker. Buletin Jendela Data \& Informasi Kesehatan, Semester 1. Kepala
Pusat Data dan Informasi Kementerian Kesehatan RI. 2015: Jakarta

2. Satin J.R, Linden W, Phillips M.J. Depression as a predictor of disease progression and mortality in cancer patients: a metaanalysis. Cancer. Wiley online library. 2009; 115: 534961

3. Krebber AM, Buffart LM, Kleijn G, et al. Prevalence of depression in cancer patients: a meta-analysis of diagnostic interview and self-report instruments. 2013; 23(2): 121-30

4. Soetrisno. Ekspresi heatshock protein 60,70 dan Kortisol pada Persalinan Ibu Primigravida yang Mendapat Psikokuratif. Disertasi. 2009. Surabaya: Universitas Airlangga

5. Smith MM, Lutgendorf SK, Sood AK. Impact of stress on cancer metastasis. Future Oncol. 2010; 6(12): 1863-81

6. Magdalena $\mathrm{F}$, Agata KF, Bogdan $\mathrm{M}$, et al. Lymphangiogenesis in cervical cancer evaluated by expression of the VEGF-C gene in clinical stage IBIIIB. Prz menopauzalny. 2015; 14(2): 112-117

7. İzci F. İlgün AS, Fındıklı E, Özmen V. Psychiatric Symptoms and Psychosocial Problems in Patients with Breast Cancer. The journal of breast health AVES. 2016; 12(3):94-101.

8. Villoria E and Lara L. Assessment of the Hospital Anxiety and Depression Scale for cancer patients. Revista médica de Chile. 2018; 146 (3): 300-7.

9. Aydogan U, Doganer YC, Komurcu S, et al. Coping Attitudes of Cancer Patients and Their Caregivers and Quality of Life of Caregivers. Indian journal of palliative care. Wolters Kluwer - Medknow Publications. 2016; 22(2): $150-6$.

10. Shim E.J and Hahm B.J. Anxiety, helplessness/ hopelessness and "desire for hastened death" in Korean cancer patients. Eur J of Cancer Care. 2011; 20(3):395-402.

11. Pinquart M, Duberstein P.R. Depression and cancer mortality: a metaanalysis. Psychol Med. 2010; 40: 17971810.

12. Nakagawa JT, Espinosa MM, Barbieri $\mathrm{M}$, et al. Cervical carcinoma: survival rate and prognostic factors in women in the state of Mato Grosso. Acta Paulista de Enfermagem. 2011; 24(5): 631-37.

13. Staufenbiel S.M, Pennix B.W, Spijker A.T, et al. Hair cortisol, stress exposure, and mental health in humans: a systematic review. Psychoenocrinology. 2013; 38: 1220-35

14. lida M, Banno K, Yanokura M. Candidate biomarkers for cervical cancer intervention. Potential for clinical practice. Molecul and Clinical Oncol. 2014; 2: 647-55. 
15. Zhang L, Chen Q, Hu J, et al. Expression of HIF- $2 \alpha$ and VEGF in Cervical Squamous Cell Carcinoma and Its Clinical Significance. Biomed Res Int. 2016.

16. Cheng D, Liang B, Li Y. Serum Vascular Endothelial Growth Factor (VEGF-C) as a Diagnostic and Prognostic Marker in Patients with Ovarian Cancer. PLoS One, 2013; 8, (2).

17. Djukanovic I, Carlsson J, Årestedt K. Is the Hospital Anxiety and Depression Scale (HADS) a valid measure in a general population $65-80$ years old? A psychometric evaluation study. Health Qual Life Outcomes. 2017; 15(1): 193

18. Widyadharma E, Rudy M, Adnyana O. Reability Indonesian Version Of The Hospital Anxiety And Depression Scale (HADS) Of Stroke Patients in Sanglah General Hospital Denpasar. Research gate.2015; 2: 1-23.

19. Graeff F, Junior ZH. The hypothalamicpituitary adrenal axis in anxiety and panic. Psychology \& Neuroscience. 2010; 3: 3-8.
20. Mehrabi E, Hajian S, Simbar $M$, et al. Coping response following a diagnosis of breast cancer : A systematic review. The Electronic physician. 2015; 7(8): 1575-83.

21. Panduan Gangguan Depresi Mayor. Perhimpunan Dokter Spesialis Kedokteran Jiwa Indonesia. Jakarta. 2013: 5-8.

22. Lutgendorf SK, Cole S, Costanzo E et al. StressRelated Mediators Stimulate Vascular Endothelial Growth Factor Secretion by Two Ovarian Cancer Cell Lines. Clinical caner research. 2003; 9(1):4514-21

23. Roberts $\mathrm{MH}$, Fletcher RB, Merrick PL. 2014. The validity and clinical utility of the hospital anxiety and depression scale (HADS) with older adult New Zealanders. Int Psychogeriatr. 2014; 26(2): 325-33. 